\title{
China contributes to the ISID in Pacific Island Countries
}

\author{
Hongfei YUE, Zhen WANG \\ Ph.d Student of Beijing Normal University \\ Post Buliding , Room1728, No.19 Xin-jie-kou-wai Street, Haidian District, 100875, Beijing, China \\ 974306532@qq.com \\ Dean of Department of Regional Programmes and Field Representation Asia and Pacific Divison of UNIDO \\ Wagramerstrasse 5,PO BOX 300, 1400 Vienna, Austria
}

ABSTRACT

z.wang@unido.org.cn

In this paper, It describes the contributes from China to prompt the inclusive and sustainable industry development of Pacific Island Countries (PICs), which is launched by UNIDO in 2013. The paper recalls China's policy towards PICs for these years and specially focuses on the financial support, economic and trade, hygiene support, capacity building as well as infrastructure. In addition, it also summarizes the 2nd China-Pacific Islands Development Forum and an overview of UNIDO projects in PICs

\section{Indexing terms/Keywords}

Pacific Island Countries(PICs), Inclusive and Sustainable Industry Development(ISID), China, UNIDO

\section{Academic Discipline And Sub-Disciplines}

Economy; International Economics and Trade

\section{SUBJECT CLASSIFICATION}

\section{Economy and Trade \\ TYPE (METHOD/APPROACH)}

Historical Inquiry and Review;

As we know, the Small Island Developing States face special challenges to their development. This is particularly true for the Pacific Island States, scattered as they are over a huge area of ocean.

More specifically, the 22 Pacific Island countries are scattered over one third of the globe (thirty million sq. km. mostly ocean). The total population of the South Pacific excluding Australia and New Zealand is about 8 million; half of which reside in Papua New Guinea.

Many stakeholders have been involving in assisting the development of Pacific Island Countries for a long time. In recent years, China has become one of the active players in the inclusive and sustainable development of Pacific Island Countries.

\section{CHINA'S POLICY TOWARDS PACIFIC ISLAND COUNTRIES (PICS)}

China firmly adheres to the path of peaceful development and pursues a policy of peace, development and cooperation in international affairs, and will continue to strengthen its friendship and cooperation with the Pacific Island Countries on the basis of the Five Principles of Peaceful Coexistence.

China maintains that all countries, whether big or small, strong or weak, rich or poor, are equal members of the international community and should treat each other equally. China shares the joy over the achievements of the Pacific Island Countries and is aware of the difficulties they face in their development endeavor..

On 5 April 2006, the first Ministerial Meeting of the China-Pacific Island Countries Economic Development and Cooperation Forum opened in Nadi, Fiji, and a "guiding framework" on economic development and cooperation had been signed between China and eight PICs, which made China's policy towards PICs focuses on specific fields and subsectors including the projects relating Inclusive and Sustainable Industrial Development (ISID).

Under the framework China has strengthened and improved bilateral consultations through increasing high-level dialogues, exchange of visits, and consultations by senior officials, so as to identify new fields and methods of economic and trade cooperation, provide zero-tariff treatment to the majority of exports to China from the least developed countries in the region that have diplomatic ties with China.

China promoted communications among their organizations and institutions, such as chamber of commerce, guild and forum of entrepreneurs, improved the information exchanges about markets, commodities, services, established a legal framework which is conducive to investment promotion and protection. The Chinese government always actively encourages Chinese enterprises, to identify good cooperation projects globally, which can give full play to their advantages, in line with the economic features of Pacific Island Countries.

The priority will be given to encouraging cooperation in the study and formulation of agricultural development programs, transfer of technical expertise, construction of agricultural infrastructure, manufacture of machines for agricultural use, 
processing of agricultural products, fishery and plant farming as well as assessment and sustainable use and development of fishery resources under the framework.

China also makes efforts to encourage enterprises to explore different types of cooperation in the fields of transportation, electric power, wind and solar energy ethnology, telecommunication, water supply, water treatment and urban planning. China and the Pacific island countries agreed to strengthen exchanges and cooperation in the field of natural resources and to make efforts to optimize utilization of resources on the basis of sustainable development.

\section{China's action in PICs}

\subsection{Financial support}

A preferential loan has been allocated to the PICs to strengthen cooperation in development of resources, agriculture, forestry, fishery, tourism, textiles and consumer products manufacturing and also be used to develop telecommunications, aviation and ocean shipping. Chinese government also set up a special fund to encourage Chinese companies to invest in the Pacific Island Countries.

In the future, China will offer the Pacific Island Countries the concessional loans of US\$1 billion to build major production projects, infrastructure and livelihood projects. China National Development Bank will set up a special loan of US\$1 billion to support the infrastructure construction of Pacific Island Countries.

\subsection{Economic and trade}

Between China and Peaceful Island Countries bilateral trade developed rapidly with an annual growth of $27 \%$. In 2012 , the trade volume reached USD 4.5 billion. China has established more than 150 enterprises in Pacific Island Countries, the investment added up to almost USD 1 billion and the amount of construction contract was beyond USD 5 billion. Bilateral personnel exchanges becoming more frequently and there have been 7 Pacific Island Countries who have become the group outbound tourist destinations for Chinese citizens. In 2012, the number of China citizens who traveled to the Island Countries added up to almost 700,000. The rapid development of economic and trade cooperation have brought genuine benefit to all parties, and narrowed the distance between People of China and Pacific Island Countries.

\subsection{Hygiene support}

China provides free anti-malaria medicines to the island countries affected by the disease help them to treat malaria and continue to send medical teams to the island countries. China conducts and conduct annual training courses for health officials, hospital managers and medical researchers of these countries, promote exchange information on bird flu prevention and control, and cooperate with the island countries in various ways in this field. The National Medical Center standing in the capital of Samoa, supported by China, significantly improved the medical condition of local people. In the future, China will continue to provide them with medical facilities, medical team, medical devices and medicines and share the antimalarial experience and technology with them

\subsection{Capacity building}

China has provided training to 2,000 government officials and technical staff from the island countries. China also has provided assistance in building an earthquake or tsunami early warning and monitoring network in light of the need of the island countries to improve their capability of managing earthquakes, tsunamis and other natural disasters. China will provide the scholarships for 2,000 students from these countries in 4 years to help them train professional technicians and will continue to support to build the primary and middle schools for Pacific Island Countries and support the Chinese teaching work, help to improve the extreme weather forecast and marine environmental monitoring in Pacific Island Countries

\subsection{Infrastructure}

The Central Business District reconstructed in Tonga's capital has become a busy shopping center, which supported by China. Y-12 aircrafts and combination cargo-passenger ships provided for parts of islands Countries greatly facilitated the transportation of local people. In the future, China will provide the low carbon products like solar street lights and energysaving appliance; help to build green energy projects relative to small hydro-electric power plants, solar energy and methane.

\section{The 2nd China-Pacific Islands Development Forum}

As a specialized agency of the United Nations promoting industrial development, United Nations Industrial Development Organization(UNIDO), with the mandate of Inclusive and Sustainable Industrial Development (ISID), has a leading role to promote green industry globally.

Over the years, UNIDO has worked with a number of the Pacific Island Countries, and plans further interventions, to support the development of local agro-processing and other industries. It has also supported the deployment of renewable energy systems to reduce the reliance of the islands on very expensive imported fuels to power their industries. But more needs to be done to support the Pacific Island States.

As invited by the organizer, LI Yong, Director General, UNIDO attended the 2nd China-Pacific Islands Development Forum held in November 2013 in Guangzhou, China. The forum was jointly sponsored by China, Cook Islands, Niue, Micronesia, Papua New Guinea, Samoa, Tonga, Vanuatu and Fiji. The Forum focused its discussions on cooperation in

2255 | P a g e 
the agricultural and fisheries sectors; on cooperation in the tourism sector; on trade and investment; and on environmental protection - all vitally important topics for the Pacific Island States.

Practical outcomes have been sought. The China International Green Innovative Products and Technologies Show also hosted an exhibition of products from the Pacific Island Countries, and that the Organizers of the Show also arranged for business negotiations between participants to the Show and enterprises from the Islands.

UNIDO stands ready to support the Forum in its efforts, in whatever way it can within its mandate, based on its experience in implementing technical cooperation projects in the Pacific Island Countries. UNIDO has been working with Pacific Island Countries since 1980's. It has implemented 111 projects with a total expenditure of US\$11,102,328. The Organization has been working with different stakeholders particularly government agencies, NGOs, donor agencies, private sectors among others in pursing the ISID of PICs.

Table 1 : The overview of UNIDO projects in PICs

\begin{tabular}{|c|c|c|}
\hline Countries & Project numbers & Total Expenditure (USD) \\
\hline Fiji & 19 & 638,846 \\
\hline Papua New Guinea & 26 & $3,524,191$ \\
\hline Vanuatu & 6 & 597,627 \\
\hline Tonga & 6 & 828,909 \\
\hline Samoa & 5 & 57,582 \\
\hline Subtotal & 62 & $5,647,155$ \\
\hline Cook Island & 3 & NA \\
\hline Kiribati & 3 & 477,444 \\
\hline Niue & 1 & NA \\
\hline Marshal Island & 6 & 95,000 \\
\hline Micronesia & 19 & $2,037,415$ \\
\hline Solomon Islands & 11 & $2,801,452$ \\
\hline Tuvalu & 1 & 43,862 \\
\hline Palau & 5 & NA \\
\hline Subtotal & 49 & $5,455,173$ \\
\hline Total & 111 & $11,102,328$ \\
\hline
\end{tabular}

Resource:UNIDO Annual Report from 1978-2013

\section{REFERENCES}

1.United Nations Industrial Development Organization, UNIDO Annual Report[R].1978-2013

2. "Chinese Company to Build Tuna Cannery in PNG",Pacific Islands Report.

3.John H. and Benjamin,R.2003. "Dragon in paradise: China's rising star in Oceania", the National Interest.

4.Wang Zuocheng, Sun Xueyan. 2014."Comprehensive review on Pacific Island Country Studies”. Pacific Journal.

\section{Author' biography}

Hongfei YUE, The PH.d student in School of Economic and Resource Management at Beijing Normal University. The filed of Education is green economics. He was an intern in UNIDO and work for department of Regional Programmes and Field Representation Asia and Pacific Divison of UNIDO. And he is the liason officer at UNIDO-UNEP Green Industry Platform China Chapter Office.

Zhen WANG,PhD degree on Economics from Nankai University (China), works as the Programme Officer in Asia-Pacific Bureau of UNIDO since 2007. He has been mainly responsible for developing partnership with member states in Asia and Pacific, facilitating regional cooperation projects, identifying country programmes as well as providing policy advice to the management. 